\title{
GLANDERS IN DONKEYS (EQUUS ASINUS) IN THE STATE OF PERNAMBUCO, BRAZIL: A CASE REPORT
}

\section{Rinaldo Aparecido Mota ${ }^{1 *}$; Andréa Alice da Fonseca Oliveira ${ }^{1}$; José Wilton Pinheiro Junior ${ }^{2}$; Leonildo Bento Galiza da Silva $^{1}$; Marilene de Farias Brito ${ }^{3}$; Silvana Suely Assis Rabelo ${ }^{1}$}

\begin{abstract}
${ }^{1}$ Departamento de Medicina Veterinária, Universidade Federal Rural de Pernambuco, Recife, PE, Brasil; ${ }^{2}$ Unidade Acadêmica de Garanhuns, Universidade Federal Rural de Pernambuco, Garanhuns, PE, Brasil; ${ }^{3}$ Universidade Federal Rural do Rio de Janeiro, Instituto Veterinário, Rio de Janeiro, RJ, Brasil.
\end{abstract}

Submitted: November 27, 2008; Returned to authors for corrections: December 08, 2008; Approved: August $22,2009$.

\begin{abstract}
The clinical, anatomical and histopatological findings of glanders diagnosis in donkeys in the state of Pernambuco-Brazil are reported. The animals were euthanized and necropsied, and evaluated for lesions in respiratory and lymphatic systems, confirming the disease by isolation of Burkholderia mallei and Strauss test.
\end{abstract}

Key words: Burkholderia mallei; epidemiology; microbiology; histopathology; Strauss test

Glanders is a highly contagious disease caused by the bacteria Burkholderia mallei affecting primarily horses, mules, and donkeys. The disease can be fatal in mules and donkeys and causes respiratory infection and skin lesions in equine and humans. Equids can be infected by close contact with other infected animals, sharing water and feed, as well as by nuzzling (direct contact). The bacteria can also be spread by fomites such as brushes, halters or harnesses. The most common sign of infection in animals is yellow-green nasal discharge, ulcers on the nose, enlarged lymph nodes and nodules on the skin. Disease in mules and donkeys can begin rapidly and lead to death in 1 to 2 weeks after exposure. Humans can get glanders by direct contact with infected animals (4). In Brazil, based on clinical-pathological, epidemiological and serological aspects, as well as by the isolation of Burkholderia mallei, foci of glanders were diagnosed in equids of the "Zona da Mata" in the states of Pernambuco and Alagoas (9). In this paper we report the clinical, anatomical and histopatological findings of glanders diagnosis in donkeys in the state of Pernambuco, Brazil.

Two adult donkeys with approximately 10 years old, directed to Veterinary Medicine Department of the Federal Rural University of Pernambuco, were studied. The animals were considered positive at serological exam (Complement Fixation) for anti-B. mallei antibodies and euthanized according to the Resolução 714 - Conselho Federal de Medicina Veterinária (CFMV-Brazil) (5) based in norms of the American Veterinary Medical Association (AVMA) (2).

Necropsy of the euthanized animals was conducted, with special attention to the respiratory and lymphatic systems. Lung tissue and nasal septum fragments were obtained and fixed in tamponade formalin at $10 \%$ following the processing routine soaked in paraffin, block section at $5 \mu$ and coloring by the technique of hematoxylin and eosine (HE).

\footnotetext{
*Corresponding Author. Mailing address: Universidade Federal Rural de Pernambuco, Departamento de Medicina Veterinária (DMV). Rua Dom Manuel de Medeiros, s/n, CEP: 52.171-900, Recife - PE, Brasil.; Tel: +55 81 3320- 6429 Fax: +55 813320 6400.; E-mail: rinaldo.mota@ @otmail.com
} 
For the bacteriological confirmation of the presence of Burkholderia mallei, samples of purulent secretions were collected by aspirative punction of closed cutaneous nodules by using hypodermic needles $40 / 12 \mathrm{~mm}$ and disposable syringes. The samples were sent to the Infectious and Contagious Diseases Laboratory of the Veterinary Medicine Department of the Federal Rural University of Pernambuco, Brazil. The purulent material was cultivated in agar basis enriched with lamb's blood at $10 \%$ and incubated at $37^{\circ} \mathrm{C}$ for 72 hours. Isolated bacterial colonies were identified based on the morphotinctorial characteristics and also underwent biochemical tests of catalase, oxidase, indole, $\mathrm{H}_{2} \mathrm{~S}$ production, methyl red, Voges Proskauer, motility, D-glucose gas, citrate, urease and carbohydrate fermentation (glucose, maltose, galactose, lactose, fructose, manose, saccharose and mannitol) (1). After bacterial identification, male and adult guinea pigs (Cavia porcellus) underwent interperitoneal inoculation of the isolates (Strauss test) (8).

The animals presented to the clinical exam hyperthermia, mucous purulent nasal discharge (Figure 1), dyspnea, noisy breathing, pulmonary stertors and ulcers in the mucosa of the nasal cavity, cachexia, lack of appetite and rosary-shaped nodules in lymphatic vessel tracts in the cervical region (Figure 2) was observed. Ulcers in the nasal cavity and septum were observed at necropsy followed by abundant purulent exsudate obstructing nostrils. Lungs had multiples abscesses and pyogranulomas with 2 to $3 \mathrm{~cm}$ of firm consistency. Round and elevated nodules were observed in the lymphatic system along the path of lymphatic vessels forming rosaries and some of them were fistulated and drained purulent contents. Those lesions were more common in the head and neck and were observed in one animal only. Superficial mandibular and cervical lymph nodes and those related to the respiratory tract were the most affected and showed an increase in volume, fibrous texture and adhered to skin.

The histopatological exam was characterized by granulomatosis or pyogranulomatosis lesions in lungs with central caseification necrosis surrounded by inflammatory elements, particularly macrophages, epithelioid cells, giant cells, lymphocytes, plasmocytes and abundant conjunctive tissue. Furthermore, a sharp congestion and small foci of hemorrhage, edema and interlobular and intra-alveolar fibrin were observed. A severe diffuse purulent inflammation with destruction of the nasal epithelium, septal glands and cartilage, fibrin foci and vasculitis were observed. There were necrosis, congestion and hemorrhage with numerous foci of pyogranulomatous inflammation in lymph nodes.

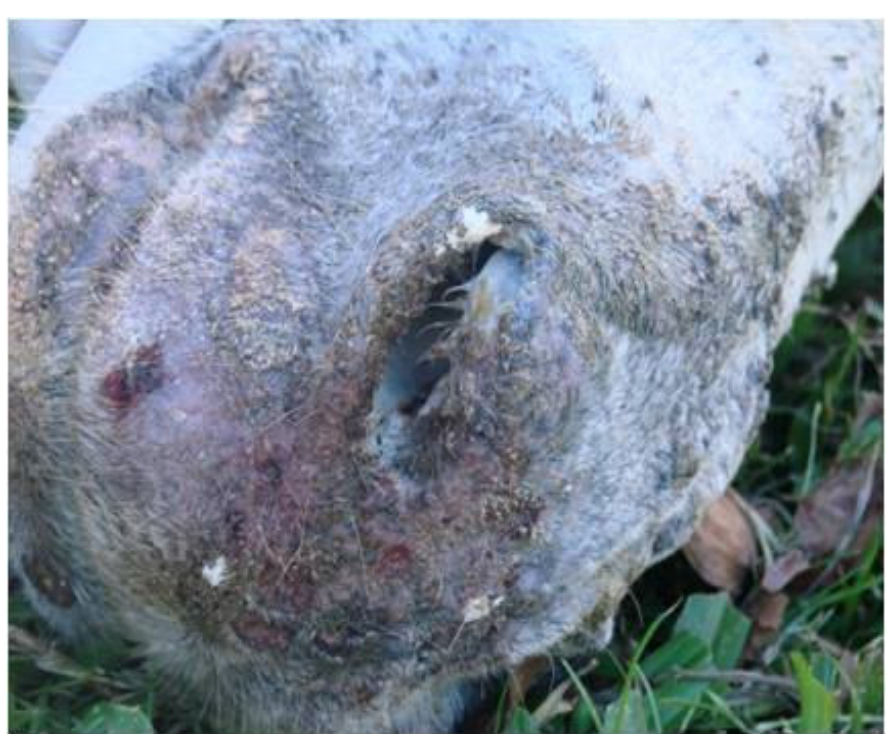

Figure 1. Purulent mucous nasal discharge in a donkey.

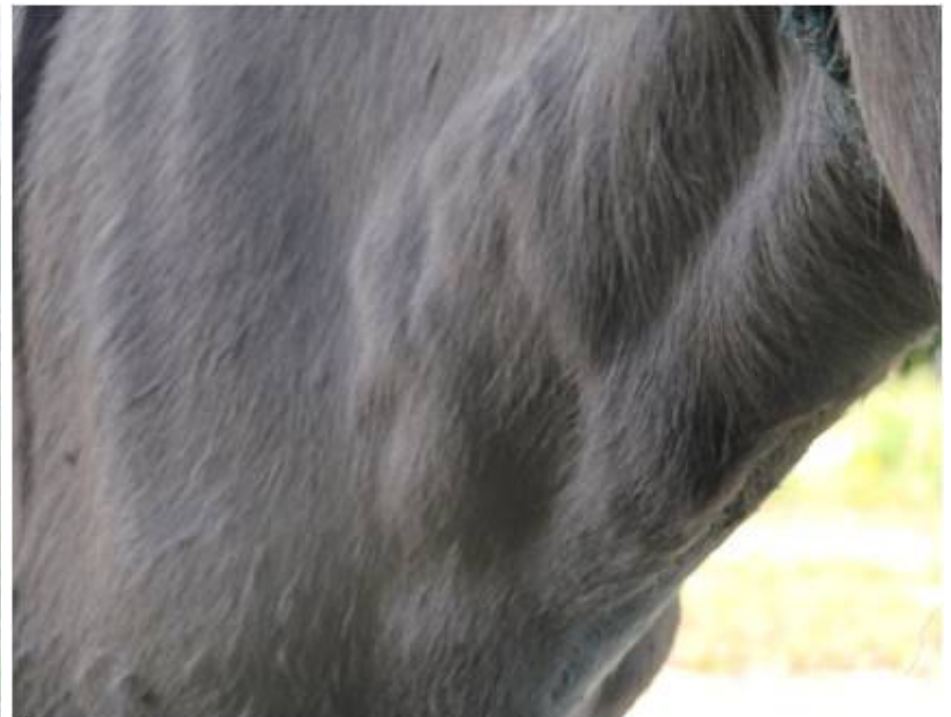

Figure 2. Nodules of lymphatic vessel tracts in the cervical region in a donkey. 
Following the aspirated pus from subcutaneous nodules, a growth of numerous small non-hemolytic colonies, having a slightly grayish coloring after 48 hours of incubation was observed. At Gram, bacteria were negative, irregular, isolated or in filaments.

The material inoculated in guinea pigs by intraperitoneal via (Strauss test) resulted in a positive reaction 96 hours after inoculation, which was characterized by severe orchitis. After euthanasia of guinea pigs $(2,5)$, purulent contents of the testicles were cultivated, what allowed bacterial reisolation.

Clinical signs observed in the animals studied were suggestive of glanders since that is a respiratory disease affecting the lymphatic system. One of the animals had sharper signs in the respiratory system with a noticeable dyspnea and noisy breathing with obstruction of nostrils by purulent exsudate. The other animal had clearer lesions in the lymphatic system, characterized by lymphangitis. Although the association of respiratory and lymphatic symptoms in the same animal is frequent, these can be observed separately. When a larger number of ill animals is observed in the same herd, that association is less evident. Those clinical signs in regions where the disease is a sanitary problem for horses show that a clinical diagnosis of the disease is necessary $(9,11)$. The association of clinical, pathological, microbiological and serological findings with biological tests, reported in this study, allows glanders to be diagnosed in donkeys. It must be said that although literature reports that the disease can also occur in horses, mules and donkeys, it is most often found in mules and horses and there are few natural cases of the disease in donkeys described in the region under study. The epidemiological data previously found by Mota et al. (9) show that it is an infectious and contagious disease of high morbidity and mortality, whose agent is resistant to the antibiotherapy used in the treatment of respiratory diseases of bacterial origin in horses. The pathological findings reported in this paper are in accordance with the glanders description $(3,6,7,8,9)$. Biochemical properties of isolated bacteria in cutaneous lesions are similar to those reported by Al-Ani et al. (1), what allows it to be classified as Burkholderia mallei. The findings related to the inoculation of bacteria are in full agreement with those results $(8,10)$.

Glanders ranks high on horse's clinical lists in some regions of Brazil as a cause for respiratory and lymphatic diseases, which were diagnosed in the late $20^{\text {th }}$ century. High frequency of this condition is found in horses under excessive work stress alongside the kind of handling often used in properties with feedlots in collective pens, which favor the dissemination of the agent in the environment, facilitating indirect horizontal infection. Other important risk factors are poor feeding, animal roaming and keeping sick animals in the herd.

It can't be stressed enough how important it is to include this bacterium in the differential diagnosis for other agents causing respiratory disease in this species in Brazil, since this bacterium is resistant to treatments that use antibiotics and other drugs and also because the disease is an important zoonosis. The knowledge of clinical signs and anatomical and histopatological lesions determined by this agent leads the practitioner to suspect glanders. The confirmation of the diagnosis, however, must be performed by means of isolation and bacterial identification, the research of antibodies and an intradermopalpebral test using bacterium's protein extract.

\section{REFERENCES}

1. Al-Ani, F.K.; Al-Rawashdeh O.F.; Ali A.H.; Hassan, F.K. (1998). Glanders in horses: clinical, biochemical and serological studies in Iraq. Vet. Archiv. 68, 155-62.

2. AVMA - American Veterinary Medical Association (2007). Guidelines on Euthanasia. Available at: http://www.avma.org/issues/animal_welfare/euthanasia.pdf. Accessed 20 may 2007.

3. Bazargani, T.T.; Tadjbakhsh, H.; Badii, A.; Zahraei, T. (1996) The outbreak of glanders in some race horses in three states of Iran. $J$. Equine Vet. Sci. 16, 232-236.

4. Center for Food Security \& Public Health (2007). Technical Fact Sheets: Glanders. Available at: http://www.cfsph.iastate.edu/DiseaseInfo. Accessed 20 June 2008.

5. CFMV - Conselho Federal de Medicina Veterinária (2000). Resolução 714 de 20 de junho de 2000. Métodos de Eutanásia. Available at: http://www.cfmv.org.br. Accessed 20 June 2008. 
6. Jubb, K.V.F.; Kennedy, P.C.; Plamer, N. (1993). Glanders. In: Jubb, K.V.F. \& Kennedy, P.C. (eds.). Pathology of Domestic Animals. Academic Press, San Diego, USA, p. 640.

7. Krishna, L.; Gupta, V.K.; Masand, M.R. (1992). Pathomorfological study of possible glanders in solipeds in himachal pradesch. Indian Vet. J. 69, 211-214.

8. Langenegger, J.; Döbereiner, J.; Lima, A.C. (1960). Foco de mormo (Malleus) na região de Campos, estado do Rio de Janeiro. Arq. Inst. Biol. 3, 91-108.
9. Mota, R.A.; Brito, M.F.; Castro, F.J.C.; Massa, M. (2000). Mormo em eqüídeos nos estados de Pernambuco e Alagoas. Pesq. Vet. Bras. 20, 155 159.

10. Muhammad, G.; Khan, M.Z.; Athar, M. (1998). Clinical, microbiological and therapeutic aspects of glanders in equines. J. Equine Sci. 9, 93-96.

11. Rabelo, S.S.A. (2003). Infecção natural pela Burkholderia mallei em muares (Equus asinus caballus) procedentes da Zona da Mata do estado de Pernambuco: Aspectos clínicos, hematológicos e bioquímicos séricos. Recife, Pernambuco, Brasil, 55 p. (D.Sc. Thesis. Departamento de Medicina Veterinária. UFRPE). 